\title{
Pengaruh Academic Stress, Achievement Motivation, dan Perceived Social Support terhadap Academic Burnout Siswa SMK
}

\author{
EKA TRANSIANA, NUR AINY FARADANA NAWANGSARI \& DUTA NURDIBYANANDARU*
}

Departemen Psikologi Perkembangan dan Pendidikan, Fakultas Psikologi Universitas Airlangga

\begin{abstract}
ABSTRAK
Penelitian ini bertujuan untuk mengetahui apakah terdapat pengaruh academic stress, achievement motivation, dan perceived social support terhadap academic burnout. Metode yang digunakan adalah kuantitatif dengan 103 partisipan siswa SMKN Surabaya. Alat ukur yang digunakan adalah skala adaptasi Educational Stress Scale for Adolescents, karakteristik achievement motivation, skala adaptasi Multidimentional Scale of Perceived Social Support, dan skala adaptasi Student Burnout Inventory. Penelitian ini menggunakan teknik analisis regresi berganda dengan bantuan IBM SPSS 22. Hasil penelitian ini menunjukkan ada pengaruh antara academic stress, achievement motivation, dan perceived social support secara simultan terhadap academic burnout dengan sumbangan sebesar 29,7\%, sedangkan sisanya dipengaruhi oleh variabel lain yang tidak dibahas dalam penelitian. Sementara itu, secara parsial hasil penelitian ini menunjukkan bahwa academic stress dan achievement motivation berpengaruh secara signifikan terhadap academic burnout, sedangkan perceived social support tidak berpengaruh secara signifikan terhadap academic burnout.
\end{abstract}

Kata kunci: academic burnout, academic stress, achievement motivation, perceived social support

\section{ABSTRACT}

This study aimed to investigate the effect of academic stress, achievement motivation, and perceived social support to academic burnout. This research used quantitative method with 103 participants of vocational high school in Surabaya. The scale of Educational Stress for Adolescents, the characteristics of achievement motivation, Multidimentional Scale of Perceived Social Support and the Student Burnout Inventory scale were used as research tools. This study used multiple regression analysis techniques with the help of IBM SPSS 22 for Windows. The results of this study indicated there was an influence between academic stress, achievement motivation, and perceived social support to academic burnout stimultaneously with contribute $29,7 \%$, while the rest were influenced by other variables not discussed in this research. Meanwhile, partially the results of this study indicated that academic stress and achievement motivation significantly influenced to academic burnout, while perceived social support did not significantly influenced to academic burnout.

Keywords: academic burnout, academic stress, achievement motivation, perceived social support

Buletin Penelitian Psikologi dan Kesehatan Mental (BRPKM), 2021, Vol. 1(1), 435-447

*Alamat korespondensi: Fakultas Psikologi Universitas Airlangga, Kampus B Universitas Airlangga Jalan Airlangga 4-6 Surabaya 60286. Surel: nurainy.faradana@psikologi.unair.ac.id 


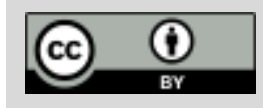

Naskah ini merupakan naskah dengan akses terbuka dibawah ketentuan the Creative Common Attribution License (CC-BY-4.0) (http://creativecommons.org/licenses/by/4.0), sehingga penggunaan, distribusi, reproduksi dalam media apapun atas artikel ini tidak dibatasi, selama sumber aslinya disitir dengan baik.

\section{PEN D A H U L U A N}

Dalam perkembangannya burnout semakin banyak dibahas bukan hanya pada kalangan orang dewasa dalam situasi kerja yang penuh tekanan saja, akan tetapi juga pada lingkungan akademik yang dikenal dengan academic burnout. Menurut Salmela-Aro dkk. (2009) burnout diartikan sebagai konstruksi tiga dimensi termasuk kelelahan emosional, sinisme, dan perasaan tidak mampu sebagai seorang siswa. Lebih lanjut Salmela-Aro dkk. (2009) menjelaskan kelelahan emosional dapat didefinisikan sebagai perasaan tegang, cemas dan kelelahan kronis yang disebabkan oleh beban berlebih pada pekerjaan sekolah. Kemudian sinisme diekspresikan melalui sikap menyendiri terhadap segala sesuatu yang terkait dengan pekerjaan sekolah serta melalui hilangnya minat pada pekerjaan akademik, dan mendevaluasi makna belajar. Sedangkan perasaan tidak mampu sebagai siswa dimanifestasikan melalui perasaan berkurangnya kompetensi, kemajuan dan keberhasilan dalam prestasi akademik.

Pada prinsipnya setiap individu memiliki peluang mengalami burnout, akan tetapi berdasarkan pengamatan dan informasi dari berbagai sumber, burnout jarang dialami oleh siswa Sekolah Dasar namun banyak dijumpai pada kalangan Mahasiswa, serta siswa Sekolah Menengah Pertama maupun Sekolah Menengah Atas atau sederajat (Thursan, 2005). Siswa SMA atau sederajat di Indonesia pada umumnya berusia antara 15-18 tahun. Menurut Mönks \& Haditono (2006) dalam perkembangannya siswa berada pada fase remaja pertengahan. Menurut Erikson \& Cremers (1989 dalam Santrock, 2003) menyatakan remaja juga identik dengan masa pencarian identitas dan dihadapkan pada berbagai pertanyaan tentang dirinya. Sementara itu, Santrock (2003) menyatakan pada masa remaja, siswa mengalami pergolakan (storm-and-stress view) yang disebabkan oleh konflik dan perubahan suasana hati.

Konflik diri yang dialami remaja membuat mereka menjadi stres dalam proses belajarnya di sekolah. Sebagaimana yang diungkapkan Elizabeth B. (2004) remaja yang tidak mampu menghadapi tuntutan pendidikan, biasanya menunjukan ketidaksenanganya terhadap mata pelajaran dengan menjadi orang yang berprestasi rendah, membolos dan berusaha memperoleh izin orangtua untuk berhenti sekolah sebelum waktunya atau ketika berada di kelas terakhir tanpa merasa perlu untuk memperoleh ijazah. Sementara itu, Salmela-Aro dkk, (2009 dalam Lin \& Huang, 2014) mengungkapkan stres yang terjadi secara terus-menerus pada individu akan berakibat pada kelelahan yang besar (burnout). Hal ini menjadi salah satu bahan pertimbangan bagi peneliti untuk memfokuskan penelitian pada burnout siswa Sekolah Menengah Kejuruan di Surabaya.

Beberapa penelitian telah dilakukan untuk mengungkap burnout di kalangan siswa Sekolah Menengah Atas atau sederajat. Berdasarkan studi ilmiah yang dilakukan Suwarjo \& Purnama (2016) pada 785 siswa SMA Negeri dan SMA Swasta di Yogyakarta, didapatkan hasil profil burnout belajar siswa menurut aspek-aspek dan faktor penyebabnya. Beberapa aspek kejenuhan belajar yang terungkap dalam penelitian ini adalah aspek kelelahan fisik (38,9\%), kelelahan emosi $(35,6 \%)$, kelelahan motivasi $(24 \%)$ dan kelelahan kognitif (20\%), sedangkan faktor penyebabnya meliputi karakteristik individu $(19,7 \%)$, lingkungan belajar $(50,0 \%)$ dan keterlibatan dengan lingkungan belajar $(35,3 \%)$. 
Penelitian lain yang juga mengungkapkan terjadinya academic burnout siswa Sekolah menengah Atas adalah Studi longitudinal yang dilakukan oleh Salmela-Aro dkk. (2008) pada 773 siswa Finlandia. Studi ini berfokus pada evolusi burnout selama masa transisi dari sekolah komprehensif ke Sekolah Menengah Atas (jalur akademik dan kejuruan). Hasil dari penelitian ini menunjukkan remaja di Sekolah Menengah Atas jalur akademik (SMA) mengalami kelelahan lebih tinggi dibandingkan siswa di sekolah kejuruan (SMK). Selain itu, sinisme dan perasan tidak mampu meningkat setelah berada di sekolah menengah jalur akademik, sementara skor ini menurun terutama bagi siswa laki-laki jalur kejuruan. Sedangkan siswa perempuan pada jalur akademik mengalami burnout yang lebih tinggi pada ketiga komponen burnout dibandingkan dengan siswa laki-laki. Temuan senada juga diungkapkan oleh Salmela-Aro \& Tynkkynen (2012) dan Bask \& Salmela-Aro (2013) bahwa siswa Finlandia dijalur akademik tampak konsisten lebih berisiko mengalami burnout dari pada mereka yang berada dijalur kejuruan. Berdasarkan beberapa penelitian ilmiah yang telah dipaparkan di atas, menunjukan bahwa baik siswa jenjang Sekolah Menengah Kejuruan (SMK) maupun Sekolah Menengah Atas (SMA) juga mengalami beberapa tingkat kejenuhan dalam proses belajarnya.

Peneliti tekankan kembali bahwa studi ini berfokus pada academic burnout siswa Sekolah Menengah Kejuruan di Surabaya. Sebagaimana telah dipaparkan sebelumnya berdasarkan penelitian yang dilakukan Salmela-Aro dkk. (2008), Salmela-Aro \& Tynkkynen (2012) dan Bask \& Salmela-Aro (2013) studi longitudinal pada remaja di Finlandia, menunjukan bahwa siswa di jalur akademik memiliki tingkat burnout yang lebih tinggi dibandingkan siswa di jalur kejuruan. Hal ini berbanding terbalik dengan data Pendidikan dan Kebudayaan di Indonesia tahun 2017/2018. Asumsi peneliti terhadap perbedaan hasil penelitian ilmiah yang dilakukan Salmela-Aro dkk. (2008), Salmela-Aro \& Tynkkynen (2012) dan Bask \& Salmela-Aro (2013) dengan data empiris yang terjadi di Indonesia dikarenakan perbedaan mendasar pada sistem pendidikan yang dianut, sehingga penelitian ilmiah disuatu negara belum tentu dapat digeneralisasikan di negara lainnya. Asumsi tersebut diperkuat dengan studi yang dilakukan oleh Bautty (2016) yang menyatakan Finlandia merupakan salah satu negara dengan sistem pendidikan terbaik dunia yang memiliki jam belajar relatif singkat 30 jam/minggu, dan meminimalisir ujian.

Di Indonesia berdasarkan Peraturan Menteri Pendidikan Dan Kebudayaan Nomor 70 Tahun 2013 terdapat perbedaan mendasar antara siswa jenjang SMA dan SMK. Perbedaan tersebut terlihat dari beban belajar siswa SMA/MA untuk kelas X, XI, dan XII masing-masing adalah 42, 44, dan 44 jam pelajaran per minggu. Sementara itu, beban belajar untuk siswa SMK/MAK adalah sebanyak 48 jam pelajaran per minggu. Selain itu, menurut Rochanah Kepala SMKN 6 Surabaya proses pembelajaran di SMK menuntut keterampilan praktik, berdeda dengan jenjang SMA yang hanya berfokus pada akademik saja. Dengan demikian jelas terdapat perbedaan mendasar antara jenjang SMA dan jenjang SMK di Indonesia (JawaPos.com, 2017).

Secara umum siswa SMA/SMK di Indonesia memiliki permasalahan dalam pendidikannya yang termasuk dalam faktor risiko burnout seperti putus sekolah dan tinggal kelas. Akan tetapi, kedua permasalahan tersebut lebih banyak dialami siswa SMK dibandingkan dengan siswa SMA. Berdasarkan Pusat Data Statistik Kementrian Pendidikan dan Kebudayaan 2017/2018 didapatkan informasi mengenai jumlah siswa putus sekolah dan mengulang jenjang SMK dan SMA dari 34 provinsi di Indonesia. Jumlah siswa putus sekolah pada jenjang SMK tercatat sebanyak 73.388 siswa, sedangkan pada jenjang SMA sebanyak 31.123 siswa, selanjutnya jumlah siswa mengulang pada jenjang SMK tercatat sebanyak 13.665 siswa sedangkan pada jenjang SMA sebanyak 9.360 siswa. Kedua 
permasalahan tersebut lebih banyak dialami siswa SMK dibandingkan dengan siswa SMA, hal ini menandakan siswa SMK lebih banyak mengalami permasalahan dalam pendidikan dibandingkan dengan siswa SMA. Selain itu, dalam surat kabar JawaPos.com (JawaPos.com, 2017) termuat berita pendidikan yang berjudul "Banyak Siswa Terpaksa Tinggal Kelas". Berita tersebut memaparkan kasus siswa tinggal kelas masih banyak terjadi di Surabaya khususnya pada siswa SMK Negeri.

Kepala SMKN 1 Surabaya Siti Rochanah mengungkapkan pada kenaikan kelas tahun ajaran 2017/2018, ada 19 siswa yang tinggal kelas XI dan 5 siswa tinggal kelas XII. Menurutnya, banyaknya siswa yang tinggal kelas disebabkan siswa tidak memiliki motivasi yang kuat, karena pembelajaran di SMK menuntut keterampilan praktik. Selanjutnya Kepala SMKN 6 Bahrun juga mengungkapkan, 25 siswa kelas X yang tinggal kelas, kemudian 11 siswa kelas XI juga gagal naik kelas XII. Siswa yang tidak naik kelas menurut Bahrun disebabkan karena sikap dan kedisiplinan seperti bolos yang sudah di luar batas toleransi, sehingga siswa tidak memenuhi Kriteria Ketuntasan Minimal. Selain itu Kepala SMKN 3 Mudianto menuturkan 50 siswa yang gagal naik kelas XI. Menurutnya kasus tersebut disebabkan siswa masuk melalui pilihan kedua sehingga terjadi ketidaksiapan dalam belajarnya (JawaPos.com, 2017).

Persentase jumlah siswa mengulang di Provinsi Jawa Timur juga disajikan dalam Pusat Data Statistika Kementrian Pendidikan dan Kebudayaan 2018/2019, tercatat dari tahun 2015/2016 hingga 2018/2019 jumlah siswa mengulang pada jenjang SMK di Provinsi Jawa Timur terus mengalami peningkatan antara $0,03 \%$ hingga $0,07 \%$ atau dari jumlah 1.729 orang pada tahun 2015/2016 hingga 2.911 orang pada tahun 2018/2019. Permasalahan siswa putus sekolah maupun tinggal kelas yang telah dipaparkan sebelumnya, memang tidak bisa dijadikan sebagai satu-satunya acuan untuk mengindikasi siswa mengalami burnout. Akan tetapi, kedua permasalahan tersebut dapat menjadi faktor risiko yang dapat meningkatkan academic burnout siswa. Sebagaimana hasil penelitian terdahulu disebutkan bahwa burnout yang terjadi pada siswa menurut Meire \& Schmeck (1985 dalam Lin \& Huang, 2014) berisiko pada meningkatnya absensi, rendahnya motivasi untuk melakukan tugas yang dibutuhkan, dan persentase putus sekolah yang tinggi. Selain itu, menurut Tuominen-Soini \& Salmela-Aro (2014) dan Vasalampi dkk. (2009) menyebabkan keterlibatan dan prestasi sekolah yang lebih rendah.

Para ahli menyebutkan beragam faktor yang mempengaruhi burnout. Mempertimbangkan hal tersebut, maka penting untuk melakukan penelitian faktor-faktor yang mempengaruhi academic burnout yang peneliti sesuaikan dengan konteks siswa. Menurut Sun dkk. (2011) academic stress merupakan salah satu sumber stres yang paling relevan terjadi pada siswa karena lingkungan sekolah adalah salah satu konteks kehidupan paling signifikan dalam tahap perkembangan siswa. Hasil penelitian Zakari dkk. (2008) menunjukkan 252 siswa sekolah menengah memiliki skor burnout dengan skala tinggi $(47,6 \%)$ yang disebabkan oleh tekanan yang berhubungan dengan sekolah yaitu academic stress. Penelitian lain yang mengaitkan antara academic stress dengan academic burnout adalah Yang \& Farn (2005) hasil penelitiannya menunjukan terdapat korelasi positif antara academic stress dan academic burnout.

Faktor lain yang mempengaruhi academic burnout siswa adalah achievement motivation. Menurut Keller dkk. (1978) achievement motivation merupakan keinginan individu untuk mencapai prestasi sesuai dengan standard yang telah ia tetapkan, bukan karena uang atau penghargaan (motivasi ekstrinsik) melainkan lebih karena kepuasan intrinsik dan keberhasilan itu sendiri. Beberapa studi ilmiah menunjukkan bahwa achievement motivation berkorelasi negatif signifikan dengan kejenuhan belajar (Fitrotin \& Prihartanti, 2018). Hal ini sejalan dengan hasil penelitian Sangpoor \& Goodarzi (2018) bahwa semakin tinggi achievement motivation siswa, maka semakin rendah academic burnout siswa. Penelitian lain yang mengaitkan achievement motivation dengan academic burnout adalah Moneta 
(2011) hasil penelitiannya menunjukkan bahwa motivasi berprestasi secara langsung mencegah setiap komponen burnout (emotional exhaustion, cynism, and reduce academic efficacy). Selain itu, kelelahan emosional secara langsung meningkatkan sinisme dan mengurangi keyakinan akademik. Studi ini juga menunjukkan bahwa karakteristik, anteseden, dan konsekuensi dari academic burnout mirip dengan burnout yang terjadi pada individu yang bekerja.

Selain dari dua faktor yang disebutkan diatas, faktor lain yang mempengaruhi academic burnout siswa adalah perceived social support. Zimet mengartikan perceived social support sebagai diterimanya dukungan yang diberikan oleh orang-orang terdekat individu meliputi dukungan keluarga, dukungan pertemanan, dan dukungan dari orang-orang yang berarti disekitar individu (Zimet dkk., 1988). Hasil studi ilmiah Sharma (2012) menunjukkan bahwa siswa dengan perceived social support yang tinggi, memiliki fungsi psikologis dan sosial individu yang tinggi, serta memiliki kemampuan untuk memecah stres ke tingkat yang dapat dikelola atau eustress. Maka secara tidak langsung temuan Sharma (2012) tersebut mengungkap bahwa perceived social support dapat mencegah terjadinya academic burnout (akibat distress berkepanjangan). Sebagaimana diperkuat hasil penelitian Kupriyanov \& Zhadanov (2014) bahwa siswa yang menunjukan pada jenis distress (stres dalam bentuk negatif) maka tingkat kejenuhan belajarnya akan semakin tinggi, sebaliknya jika eustress yang lebih dominan, maka tingkat kejenuhan belajar akan semakin rendah.

Dari uraian diatas, maka konsekuensi dari academic burnout menjadi masalah akademik yang dapat menghambat produktivitas belajar serta merusak kinerja akademik siswa, sehingga mengakibatkan tidak berkembangnya seluruh potensi yang dimiliki siswa, apalagi jika hal ini terjadi pada siswa Sekolah Menengah Atas atau sederajat, maka akan berisiko pada keberhasilan dalam dunia kerja dan program studi selanjutnya. Penelitian ini merupakan pengembangan dari penelitian sebelumnya yang akan membuktikan beberapa faktor yang mempengaruhi academic burnout siswa, yaitu academic stress, achievement motivation, dan perceived social support. Ketiga faktor tersebut merupakan faktor internal (academic stress, achievement motivation) dan eksternal (perceived social support) yang menjadi penyebab munculnya academic burnout siswa.

\section{Desain Penelitian}

\section{E T O D E}

Penelitian ini menggunakan pendekatan penelitian kuantitatif. Ditinjau dari tujuan penelitian, maka penelitian ini termasuk dalam tipe penelitian penjelasan (explanatory research). Peneliti menggunakan tipe penelitian ini karena terkait dengan tujuan penelitian yaitu menjelaskan pengaruh academic stress, achievement motivation, dan perceived social support terhadap academic burnout.

\section{Partisipan}

Partisipan adalah siswa kelas X SMK Negeri Surabaya jurusan Teknik Audio Video (TAV) dan Bisnis Konstruksi dan Properti (BKP) tahun pelajaran 2019/2020. Penentuan partisipan penelitian didasarkan pada hasil survei dan wawancara peneliti dengan Kepala Koordinator Bimbingan Konseling (BK), yang menunjukkan bahwa siswa terindikasi mengalami burnout dalam aktivitas belajarnya yang diekspresikan melalui hilangnya minat pada pekerjaan akademik, mendevaluasi makna belajar serta perasaan kelelahan terhadap tugas akademik dan rendahnya motivasi siswa. Banyaknya partisipan yang digunakan dalam penelitian ini ditentukan berdasarkan tabel Krejcie \& Morgan (1970 dalam Sekaran, 2006) dengan tingkat kesalahan 5\%. Jumlah populasi (N) dalam penelian ini adalah 143 orang, dengan demikian berdasarkan tabel Krejcie \& Morgan (1970), sampel (n) yang dibutuhkan adalah 
sebanyak 103 orang. Adapun pemilihan partisipan dalam penelitian ini dilakukan dengan teknik simple random sampling yang dilakukan dengan membagikan instrumen penelitian kepada seluruh populasi penelitian terlebih dahulu, baru kemudian peneliti mengambil secara random partisipan penelitian untuk memenuhi jumlah partisipan yang dibutuhkan. Pada penelitian ini disajikan gambaran demografi partisipan yaitu jenis kelamin dan usia partisipan. Partisipan berjenis kelamin laki-laki usia 15 tahun berjumlah (41 siswa), 16 tahun (41 siswa), 17 tahun (6 siswa), sedangkan partisipan berjenis kelamin perempuan usia 15 tahun berjumlah ( 8 siswa), 16 tahun ( 6 siswa), dan 18 tahun ( 1 siswa).

\section{Pengukuran}

Ada empat jenis skala yang digunakan untuk mengukur empat variabel dalam penelitian ini. Tiga skala tentang academic stress, perceived social support, dan academic burnout tidak dilakukan pengujian reliabilitas karena merupakan skala yang diadaptasi peneliti dari skala sebelumnya yang telah memenuhi persyaratan validitas dan reliabilitas, sedangkan skala achievement motivation dilakukan pengujian validitas dan reliabilitas karena merupakan skala yang dikembangkan oleh peneliti berdasarkan karakteristik achievement motivation yang diungkapkan oleh Keller dkk. (1978) yang berfokus pada motivasi berprestasi individu dalam konteks sekolah. Aitem pernyataan dalam skala achievement motivation berjumlah 30 aitem yang terdiri dari 18 aitem favorable dan 12 aitem unfavorable dengan 5 pilihan jawaban pada skala Likert. Setelah dilakukan uji validitas aitem terdapat tiga butir instrument memiliki nilai $r$ hitung $\leq 0,235$ sehingga butir aitem tersebut dinyatakan gugur. Demikian tersisa 27 butir instrumen yang dinyatakan sahih dengan nilai koefisien reliabilitas yang kuat $(\alpha=0.845) . ”$.

Pengukuran Perceived social support dioperasionalkan dengan skor yang diperoleh dari alat ukur yang peneliti adaptasi dari Multidimensional Scale of Perceived Social Support (MSPSS) yang dikembangkan oleh Zimet dkk. (1988). Alat ukur ini terdiri dari 12 aitem favorable dengan 7 pilihan jawaban pada skala Likert (1= "sangat tidak setuju", 7= "sangat setuju") dan memiliki nilai koefisien reliabilitas yang kuat $(\alpha=.88)$.". Aitem-aitem pada skala ini mengukur penilaian subjektif individu mengenai dukungan sosial yang diterima dari tiga sumber, yaitu keluarga, teman, dan seseorang yang spesial saat dibutuhkan.

Pengukuran academic burnout dioperasionalkan dengan menggunakan skala adaptasi yang dikembangkan oleh Salmela-Aro dkk. (2009), yaitu Student Burnout Inventory (SBI). Pada awalnya SBI dikembangkan dari Bergen Burnout Inventory (BBI) yang terdiri tiga dimensi yaitu kelelahan kerja, sinisme terhadap pekerjaan, dan rasa tidak mampu di tempat kerja. Student Burnout Inventory (SBI) dibangun dengan mengubah konteks kerja ke konteks sekolah. Alat ukur ini terdiri dari 9 aitem favorable dengan 6 pilihan jawaban pada skala Likert (1= "agak tidak setuju", 6= "sangat setuju") dan memiliki nilai koefisien reliabilitas yang kuat $(\alpha=.88)$.". Skala ini mengukur tiga dimensi academic burnout, diantaranya yaitu: kelelahan pada pekerjaan sekolah, sinisme, dan perasaan tidak mampu sebagai seorang siswa.

Pengukuran academic stress dioperasionalkan dengan skor yang diperoleh dari alat ukur yang peneliti adaptasi dari Educational Stress Scale for Adolescents (ESSA) yang dikembangkan Sun dkk. (2011). Pengembangan skala pengukuran ESSA didasarkan pada tinjuan luas literatur Inggris dan Cina, serta merupakan hasil diskusi dengan para profesional bidang pendidikan dan kesehatan masyarakat di Cina. Selain itu, lima dimensi laten yang ditentukan dalam Educational Stress Scale for Adolescents (ESSA) juga berasal dari adaptasi pengukuran Academic Expectation Stress Inventory (AESI) yang dikembangkan oleh Ang dah Huang (2006). Skala Educational Stress Scale for Adolescents (ESSA) mengukur lima 
dimensi academic stress yaitu tekanan pada kegiatan belajar, beban kerja/tugas, kekhawatiran terhadap nilai, harapan terhadap diri sendiri, dan keputusasaan. Alat ukur ini terdiri dari 16 aitem favorable dengan 5 pilihan jawaban pada skala Likert (1= "tidak setuju", 6= "sangat setuju") dan memiliki nilai koefisien reliabilitas yang kuat $(\alpha=.81) . ”$.

\section{Analisis Data}

Analisis data yang digunakan dalam penelitian ini adalah analisis regresi berganda dengan bantuan IBM SPSS 22 for windows. Teknik analisis ini digunakan peneliti untuk melihat besar kecilnya pengaruh variabel academic stress, achievement motivation, dan perceived social support terhadap variabel academic burnout.

\section{HAS I L P E N EL I T IA N}

Sebelum dilakukan uji hipotesis dengan teknik regresi linier berganda, peneliti melakukan uji asumsi terlebih dahulu diantaranya yaitu: uji normalitas, linieritas, heteroskedastisitas, autokorelasi, dan multikolinieritas. Ada beberapa macam uji hipotesis yang dilakukan dalam penelitian ini yaitu uji f, analisis determinasi (adjusted $R$ square) dan uji t.

Hasil analisis regresi berganda secara bersama-sama atau uji f diketahui nilai F hitung sebesar 13,958 dengan signifikansi 0,000. Untuk mengetahui apakah hipotesis diterima atau ditolak, maka perlu menentukan $\mathrm{F}$ tabel terlebih dahulu. Penentuan nilai $\mathrm{F}$ tabel dalam penelitian ini dilakukan dengan bantuan IBM SPSS, sehingga didapatkan nilai $\mathrm{F}$ tabel 2,70. Jika dibandingkan maka $\mathrm{F}$ hitung $\geq \mathrm{F}$ tabel atau $(13,958 \geq 2,70)$ dan nilai signifikansi $0,000 \leq 0,05$, maka dapat disimpulan bahwa dalam uji ini hipotesis diterima yang berarti bahwa antara variabel academic stress $\left(\mathrm{X}_{1}\right)$, achievement motivation $\left(\mathrm{X}_{2}\right)$, maupun perceived social support $\left(\mathrm{X}_{3}\right)$ secara simultan/bersama-sama berpengaruh signifikan terhadap academic burnout (Y). Selanjutnya dilakukan pula uji determinasi untuk mengetahui besarnya pengaruh variabel independen $\left(\mathrm{X}_{1}, \mathrm{X}_{2}\right.$, dan $\left.\mathrm{X}_{3}\right)$ terhadap variabel dependen $\mathrm{Y}$ (academic burnout).

Berdasarkan hasil uji determinasi dengan IBM SPSS diketahui nilai $\mathrm{R}^{2}$ ( $R$ Square) sebesar 0,297 atau $29,7 \%$. Nilai tersebut menunjukkan bahwa prosentase sumbangan pengaruh variabel independen (academic stress, achievement motivation, dan perceived social support) terhadap variabel dependen (academic burnout) adalah sebesar 29,7\%. Hal ini berarti variabel academic stress, achievement motivation, dan perceived social support mampu menjelaskan sebesar $29,7 \%$ variasi variabel academic burnout, sedangkan sisanya sebesar 70,3\% dipengaruhi oleh variabel lain yang tidak dibahas dalam penelitian ini. Selain dari pada itu, dilakukan pula uji t yang difungsikan untuk mengetahui apakah dalam model regresi variabel independen atau variabel bebas secara parsial berpengaruh pada variabel dependen atau variabel terikat.

Hasil uji koefisien regresi secara parsial (Uji t) didapatkan nilai Signifikansi variabel academic stress $(, 000)$ dan achievement motivation $(, 001)$, keduanya memiliki nilai Sig. $<0,05$, maka dapat dinyatakan terdapat pengaruh antara variabel academic stress dan achievement motivation terdapat academic burnout secara parsial. Sedangkan pada variabel perceived social support nilai Sig. > 0,05 yaitu sebesar $(0,213)$ maka dinyatakan variabel perceived social support secara parsial tidak berpengaruh terhadap academic burnout. 


\section{I S K U S I}

Hasil penelitian membuktikan bahwa hipotesis yang telah disusun dalam penelitian ini diterima, yaitu terdapat pengaruh antara academic stress, achievement motivation, dan perceived social support terhadap academic burnout siswa Sekolah Menengah Kejuruan. Hal ini berarti semakin tinggi tingkat academic stress siswa dan semakin rendah achievement motivation serta perceived social support siswa, maka semakin tinggi tingkat academic burnout siswa, begitu sebaliknya semakin rendah academic stress siswa dan semakin tinggi tingkat achievement motivation serta perceived social support siswa, maka semakin rendah academic burnout siswa.

Academic stress merupakan salah satu jenis stres yang sering diidentifikasi terjadi pada siswa. Hal ini diperkuat dengan pendapat Taufik \& Ifdil (2013 dalam Barseli \& Ifdil, 2017) yang menyatakan bahwa stres yang sering dialami oleh siswa adalah stres akademik yang mengacu pada tekanan dan tuntutan yang bersumber dari kegiatan akademik. Selain itu, Sun dkk. (2011) juga menyatakan pembelajaran akademik merupakan salah satu sumber stres yang paling relevan terjadi pada remaja, karena lingkungan sekolah adalah salah satu konteks kehidupan paling signifikan dalam tahap perkembangan siswa. Menurut salah seorang Kepala SMKN Surabaya, proses pembelajaran di SMK tidak seperti pada sekolah tingkat menengah pada umumnya, hal ini karena pembelajaran di SMK tidak hanya berfokus pada kegiatan secara teoritis saja, namun juga menuntut keterampilan praktik, sehingga siswa harus memiliki kesiapan baik secara fisik maupun psikis (JawaPos.com, 2017).

Berbicara mengenai stress, secara teori memang sangat dekat kaitannya dengan burnout, akan tetapi tidak semua stres yang dialami individu akan sampai pada burnout. Pada dasarnya burnout tidak terjadi dalam waktu yang singkat, namun merupakan sebuah proses panjang yang terjadi secara bertahap. Menurut (Hallsten, 2005 dalam Munko, 2017) ketika strategi mengatasi stres yang dilakukan individu gagal dan kapasitas fungsional dalam diri individu berkurang maka akan mengakibatkan stres yang berulang hingga sampailah pada fase kelelahan (burnout) itu sendiri. Sama halnya dengan (Salmela-Aro et al., 2009 dalam Lin \& Huang, 2014) yang menyatakan stres yang terjadi secara terus-menerus dan dalam waktu yang lama akan berakibat pada kelelahan yang besar (burnout). Academic stress dalam penelitian ini mengarah pada persepsi maladatif siswa terhadap stressor akademik atau yang dikategorikan sebagai distress (mereaksi stres dengan cara negatif).

Hasil penelitian penulis yang menyatakan ada pengaruh academic stress terhadap academic burnout senada dengan beberapa penelitian ilmiah sebelumnya. Hasil penelitian Zakari dkk. (2008) menunjukkan 252 siswa sekolah menengah yang berpartisipasi dalam penelitian memiliki skor burnout dengan skala tinggi $(47,6 \%)$ yang disebabkan oleh tekanan yang berhubungan dengan sekolah yaitu academic stress. Hal ini sejalan dengan hasil penelitian Walburg (2014) yang menunjukan bahwa academic stress merupakan prediktor utama dari academic burnout siswa, selain tekanan yang diberikan oleh orang tua dan teman sebaya. Penelitian lain yang mengaitkan antara academic stress dengan academic burnout adalah penelitian yang dilakukan Kim \& Jang (2016) yang menunjukkan bahwa academic stress memiliki pengaruh signifikan pada academic burnout dan keterlibatan akademik. Semakin tinggi academic stress siswa, maka semakin tinggi academic burnout dan semakin rendah keterlibatan akademiknya. Demikian pula Głebocka \& Lisowska (2007) menyimpulakan bahwa stress memiliki signifikansi yang tidak dipertanyakan dalam fenomena burnout, terutama ketika stress terjadi dalam waktu yang lama dan individu tidak mampu mengelola stress.

Hasil dari penelitian ini untuk variabel achievement motivation secara parsial menunjukkan ada pengaruh achievement motivation terhadap academic burnout siswa. Achievement motivation atau 
motivasi berprestasi memiliki peranan penting dalam keberhasilan proses belajar siswa. Menurut Atkinson dkk. (2010 dalam Santrock, 2003) seseorang yang memiliki achievement motivation yang tinggi, memiliki harapan untuk sukses yang lebih besar daripada ketakutan akan kegagalan, serta tekun pada setiap usahanya ketika menghadapi tugas dan keadaan sulit. Hal ini senada dengan pendapat Dwija (2008) yang menyatakan bahwa motivasi berprestasi merupakan bentuk spesifik dari motivasi intrinsik dan dalam bidang akademik perananya sangat menentukan agar tercapai prestasi belajar yang bermakna. Siti Rochanah salah seorang Kepala SMKN di Surabaya menyatakan tanpa adanya motivasi yang kuat siswa cenderung enggan meningkatkan keterampilannya, oleh karena itu motivasi merupakan salah satu bagian terpenting dalam proses pembelajaran (JawaPos.com, 2017).

Hasil penelitian penulis yang menyatakan ada pengaruh achievement motivation terhadap academic burnout senada dengan beberapa penelitian ilmiah sebelumnya. Studi ilmiah yang dilakukan Fitrotin \& Prihartanti (2018) menunjukkan bahwa achievement motivation berkorelasi negatif signifikan dengan kejenuhan belajar. Hal ini sejalan dengan hasil penelitian Sangpoor \& Goodarzi (2018) yang menunjukkan bahwa semakin tinggi achievement motivation siswa, maka semakin rendah academic burnout siswa. Penelitian lain yang mengaitkan achievement motivation dengan academic burnout adalah penelitian Moneta (2011) hasil penelitiannya menunjukkan bahwa motivasi berprestasi secara langsung mencegah setiap komponen burnout (emotional exhaustion, cynism, and reduce academic efficacy). Selain itu, kelelahan emosional secara langsung meningkatkan sinisme dan mengurangi keyakinan akademik. Studi ini juga menunjukkan bahwa karakteristik, anteseden, dan konsekuensi dari academic burnout mirip dengan burnout yang terjadi pada individu yang bekerja. Selanjutnya hasil studi Soliemanifar dkk. (2013) menunjukkan bahwa academic achievement motivation khususnya motivasi intrinsik, dan amotivasi memainkan peran utama dalam memprediksi academic burnout siswa.

Hasil dari penelitian ini untuk variabel perceived social support secara parsial menunjukkan perceived social support tidak berpengaruh terhadap academic burnout siswa. Perceived social support merupakan salah satu faktor eksternal yang mempengaruhi academic burnout. López \& Cooper (n.d. dalam Brian, 2014) mengartikan perceived social support sebagai appresial kognitif dari individu mengenai social support yang mereka terima atau rasakan. Sumber dari dukungan ini adalah keluarga, teman, dan significant others. Menurut Agustin (2009) orang tua yang tidak peduli, atau kurangnya apresiasi keluarga terhadap prestasi siswa, turut berperan menimbulkan kejenuhan belajar. Selain itu menurut Rozsy (2018) dukungan teman sebaya juga memiliki peranan penting dalam proses belajar. Dengan dukungan sosial dari teman sebaya, siswa memiliki motivasi yang tinggi dan keyakinan diri dalam menyelesaikan tugas-tugas maupun permasalahan akademik sehingga akan terhindar dari burnout. Hasil penelitian Kutsal \& Bilge (2012) menunjukkan bahwa tingkat burnout siswa dapat diprediksi melalui tingkat dukungan sosial yang dirasakan. Selain itu Yang \& Farn (2005) dalam penelitiannya menyatakan ketika individu menyadari bahwa mereka mendapatkan dukungan sosial dari orang disekitarnya, maka hal itu dapat meningkatkan kesehatan mental dan fisik serta memainkan peran utama dalam mengatasi burnout akademik, karena faktanya perceived social support dapat mengurangi stres yang berasal dari lingkungan akademik.

Beberapa penelitian termutakhir di atas tidak senada dengan hasil penelitian penulis yang menyatakan bahwa perceived social support tidak berpengaruh terhadap academic burnout. Penulis juga mendapati bahwa perceived social support tidak mampu mempengaruhi tingkat academic burnout responden penelitian. Hal ini berarti data penelitian tidak berhasil membuktikan keterkaitan antara variabel perceived social support terhadap variabel academic burnout. Hasil penelitian penulis relevan dengan hasil penelitian yang dilakukan Harnida (2015) bahwa tinggi rendahnya dukungan sosial yang 
dipersepsikan tidak berpengaruh terhadap tingkat burnout seseorang. Hal ini senada dengan hasil penelitian Prijayanti (2015) yang menunjukkan bahwa tidak ada pengaruh yang signifikan antara persepsi dukungan sosial terhadap burnout.

\section{S I M P U L A N}

Berdasarkan analisis data yang telah dilakukan sebelumnya, dapat disimpulkan bahwa hipotesis dalam penelitian ini diterima, yaitu terdapat pengaruh signifikan antara academic stress, achievement motivation, dan perceived social support terhadap academic burnout. Hal ini menunjukkan semakin tinggi tingkat academic stress siswa dan semakin rendah achievement motivation serta perceived social support siswa, maka semakin tinggi tingkat academic burnout siswa, begitu sebaliknya semakin rendah academic stress siswa dan semakin tinggi tingkat achievement motivation serta perceived social support siswa, maka semakin rendah academic burnout siswa.

\section{U C A P A N T E R I MAKASIH}

Proses penyusunan penelitian ini tidak akan berjalan lancar tanpa adanya bantuan dari berbagai pihak yang telah memberikan dukungan, arahan, pencerahan, serta do'a demi terselesaikannya penelitian ini. Untuk itu penulis mengucapkan terima kasih yang sebesar-besarnya kepada:

1. Dr. Nur Ainy Faradana Nawangsari, M.Si., Psikolog selaku dosen pembimbing I yang selalu mengarahkan, memberikan masukan, serta memotivasi penulis.

2. Dr. Duta Nurdibyanandaru, M.S., Psikolog selaku dosen pembimbing II yang selalu mengarahkan, memberikan masukan, serta memotivasi penulis.

3. Kepala Sekolah, Staff Pengajar, dan Siswa SMK Negeri 3 Surabaya yang telah memberikan kesempatan kepada penulis untuk mengambil data serta membantu dalam menyelesaikan penulisan.

4. Dra. Cynthia Corina Eva P. selaku Kepala Koordinator Bimbingan Konseling yang telah begitu banyak memberikan informasi serta membantu penulis dalam mengambil data penelitian.

5. Seluruh Bapak dan Ibu Dosen Fakultas Psikologi atas ilmu yang telah diberikan selama peneliti menuntut ilmu di Fakultas Psikologi Universitas Airlangga Surabaya.

6. Partisipan yang secara langsung atau tidak langsung ikut membantu hingga terselesaikannya tugas akhir peneliti

\section{DEKLARASI POTENSI TERJADINYAKONFLIK KEPENTINGAN}

Eka Transiana, Nur Ainy Fardana N., dan Duta Nurdibyanandaru tidak bekerja, menjadi konsultan, memiliki saham, atau menerima dana dari perusahaan atau organisasi manapun yang mungkin akan mengambil untung dari diterbitkannya naskah ini.

\section{PUSTAKA ACUAN}

Agustin, M. (2009). Profil Kejenuhan Belajar Mahasiswa. Jurnal Pedagogia, 9(2), 16-25. 
Ang, R. P., \& Huan, V. S. (2006). Academic Expectations Stress Inventory: Development, Factor Analysis, Reliability, and Validity. Educational and Psychological Measurement, 66(3), 522-539. https://doi.org/10.1177/0013164405282461

Atkinson, Rita, L., \& Kusuma, W. (2010). Pengantar Psikologi (Jilid 2). Interkasara Publisher.

Barseli, M., \& Ifdil, I. (2017). Konsep Stres Akademik Siswa. Jurnal Konseling Dan Pendidikan, 5(3), 143. https://doi.org/10.29210/119800

Bask, M., \& Salmela-Aro, K. (2013). Burned out to drop out: Exploring the relationship between school burnout and school dropout. European Journal of Psychology of Education, 28(2), 511-528. https://doi.org/10.1007/s10212-012-0126-5

Bautty, S. N. (2016). Telaah sistem pendidikan di finlandia dan relevansinya dengan sistem pendidikan islam di indonesia(Kajian terhadap buku finnish lessons: Mengajar lebih sedikit, belajar lebih banyak ala finlandia karya pasi sahlberg). UIN SUNAN KALIJAGA.

Brian, L. (2014). Perceived social support and happiness: The role of personality and relatoinal processes. Oxford Handbook of Happiness, 847-859.

Dwija, I. W. (2008). Hubungan antara konsep diri, motivasi berprestasi dan perhatian orang tua dengan hasil belajar sosiologi pada siswa kelas II Sekolah Menengah Atas Unggulan di kota Amlapura. Undiksa, 1, 17.

Elizabeth B, H. (2004). Psikologi perkembangan. PT. Gelora Aksara Pratama.

Erikson, E., \& Cremers, A. (1989). Identitas dan siklus hidup manusia: (Bunga Rampai 1). PT Gramedia.

Fitrotin, K., \& Prihartanti, N. (2018). Hubungan antara motivasi berprestasi dan dukungan sosial orang tua dengan kejenuhan belajar siswa [Universitas Muhammadiyah]. http://eprints.ums.ac.id/60223/

Głebocka, A., \& Lisowska, E. (2007). Professional burnout and stress among Polish physicians explained by the Hobfoll resources theory. Journal of Physiology and Pharmacology: An Official Journal of the Polish Physiological Society, 58 Suppl 5(Pt 1), 243-252.

Hallsten, L. (2005). 34 burnout and wornout: Concepts and data from a national survey. Research Companion to OrganizationalHealt Psychology, 516-536.

Harnida, H. (2015). Hubungan Efikasi Diri Dan Dukungan Sosial Dengan Burnout Pada Perawat. Persona:Jurnal Psikologi Indonesia, 4(1). https://doi.org/10.30996/persona.v4i1.487

JawaPos.com. (2017, June 17). Banyak siswa terpaksa tinggal kelas. https://www.jawapos.com/nasional/pendidikan/17/06/2017/banyak-siswa-terpaksatinggal-kelas/

Keller, Kelley, \& Dodge. (1978). Motivation in school: Practitioner guide to concept and measure of motivation syracuse. ERIC. Clearing Houseon Information Resources, Suracuse University.

Kim, H.-W., \& Jang, Y.-0. (2016). The Influence of Adolescents' Academic Stress on Academic Burnout and Academic Engagement: Focusing on the Moderating Effects of Parental Academic Involvement Behavior. Journal of Korean Home Management Association, 34(5), 99-117. https://doi.org/10.7466/JKHMA.2016.34.5.99 
Krejcie, R. V., \& Morgan, D. W. (1970). Ditermining sample size research for activities. Educational and Psychological Measurement, 30, 607-610.

Kupriyanov, R., \& Zhadanov, R. (2014). The eustress concept: Problems and outlooks. World Journal of Medical Sciences. World Journal of Medical Sciences, 2(11), 179-185. https://doi.org/10.5829/idosi.wjms.2014.11.2.8433

Kutsal, D., \& Bilge, F. (2012). A study on the burnout and social support levels of high school students. Education and Science, 37(164), 243-297.

Lin, S.-H., \& Huang, Y.-C. (2014). Life stress and academic burnout. Active Learning in Higher Education, 15(1), 77-90. https://doi.org/10.1177/1469787413514651

López, M. L., \& Cooper, L. (n.d.). Social Support Measures Review. 115.

Meire, S. F., \& Schmeck, R. R. (1985). The burned-out college student: A descriptive profile. Journal of College Student Personal, 26, 63-69.

Moneta, G. B. (2011). Need for achievement, burnout, and intention to leave: Testing an occupational model in educational settings. Personality and Individual Differences, 50(2), 274-278. https://doi.org/10.1016/j.paid.2010.10.002

Mönks, F. J., \& Haditono, S. R. (2006). Psikologi perkembangan: Pengantar dalam berbagai bagiannya. Gadjah Mada University Press.

Munko, Y. (2017). Academic burnout among high-school students in Kazakhstan: The protective role of personality and academic motivation. Nazarbayev University Graduate School of Education.

Prijayanti, I. (2015). FAKULTAS PSIKOLOGI UNIVERSITAS ISLAM NEGERI SYARIF HIDAYATULLAH JAKARTA 1436 H / 2015 M. 109.

Rozsy, M. F. (2018). Hubungan Antara Dukungan Emosional Teman Sebaya dengan Burnout pada Mahasiswa Program Studi Sarjana Keperawatan Fakultas Keperawatan Universitas Jember. Universitas Jember.

Salmela-Aro, K., Kiuru, N., Leskinen, E., \& Nurmi, J.-E. (2009). School Burnout Inventory (SBI): Reliability and Validity. European Journal of Psychological Assessment, 25(1), 48-57. https://doi.org/10.1027/1015-5759.25.1.48

Salmela-Aro, K., Kiuru, N., \& Nurmi, J.-E. (2008). The role of educational track in adolescents' school burnout: A longitudinal study. British Journal of Educational Psychology, 78(4), 663-689. https://doi.org/10.1348/000709908X281628

Salmela-Aro, K., \& Tynkkynen, L. (2012). Gendered pathways in school burnout among adolescents. Journal of Adolescence, 35(4), 929-939. https://doi.org/10.1016/j.adolescence.2012.01.001

Sangpoor, K., \& Goodarzi, K. (2018). THE RELATIONSHIP BETWEEN MINDFULNESS, LIFE SATISFACTION AND ACHIEVEMENT MOTIVATION WITH ACADEMIC BURNOUT IN STUDENTS. 3, 18.

Santrock, J. W. (2003). Adolescence: Perkembangan remaja (ke enam). Erlangga.

Sekaran, U. (2006). Metodologi penelitian untuk bisnis. Salemba.

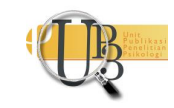


Sharma, M. (2012). The role of perceived social support in adolescents with academic stress. Jurnal of the Indian Academy of Applied Psychology, 38(1), 149-155.

Soliemanifar, 0., Farzaneh, S., \& Zekrollah, M. (2013). The relationship between of academic achievement motivation and academic burnout in postgraduate students of Shahid Chamran University of Ahvaz. Journal of Life Science and Biomedicine, 3(3).

Statistik Persekolahan SMK 2018/2019. Pusat Data dan Statistik Pendidikan dan Kebudayaan Jakarta. (2019). http://vervalstat.data.kemdikbud.go.id/

Sun, J., Dunne, M. P., Hou, X., \& Xu, A. (2011). Educational Stress Scale for Adolescents: Development, Validity, and Reliability With Chinese Students. Journal of Psychoeducational Assessment, 29(6), 534-546. https://doi.org/10.1177/0734282910394976

Suwarjo, D., \& Purnama, D. S. (2016). Model bimbingan pengembangan kompetensi pribadi sosial bagi siswa sma yang mengalami kejenuhan belajar(Burnout). Artikel Penelitian Hibah Bersaing. http://eprints.uny.ac.id/47613/

Taufik, T., \& Ifdil, I. (2013). Kondisi Stres Akademik Siswa SMA Negeri di Kota Padang. Jurnal Konseling Dan Pendidikan, 1(2), 143. https://doi.org/10.29210/12200

Thursan, H. (2005). Belajar Secara Efektif. Puspa Swara.

Tuominen-Soini, H., \& Salmela-Aro, K. (2014). Schoolwork engagement and burnout among Finnish high school students and young adults: Profiles, progressions, and educational outcomes. Developmental Psychology, 50(3), 649-662. https://doi.org/10.1037/a0033898

Vasalampi, K., Salmela-Aro, K., \& Nurmi, J.-E. (2009). Vasalampi, K., Salmela-Aro, K., \& Nurmi, J. (2009). Adolescents' self-concordance school engagement, and burnout predict their educational trajectories. , 14, 332-341. European Psychologist, 14, 332-341.

Walburg, V. (2014). Burnout among high school students: A literature review. Children and Youth Services Review, 42, 28-33. https://doi.org/10.1016/j.childyouth.2014.03.020

Yang, H.-J., \& Farn, C. K. (2005). An investigation the factors affecting MIS student burnout in technicalvocational college. Computers in Human Behavior, 21(6), 917-932. https://doi.org/10.1016/j.chb.2004.03.001

Zakari, S., Walburg, V., \& Chabrol, H. (2008). Study of burnout, depression and suicidal thoughts among French high-school students. Journal de Thérapie Comportementale et Cognitive, 18, 113-118.

Zimet, G. D., Dahlem, N. W., Zimet, S. G., \& Farley, G. K. (1988). The Multidimensional Scale of Perceived Social Support. Journal of Personality Assessment, 52(1), 30-41. https://doi.org/10.1207/s15327752jpa5201_2 